\title{
CEDNIK syndrome
}

INSERM

\section{Source}

INSERM. (1999). Orphanet: an online rare disease and orphan drug data base. CEDNIK syndrome. ORPHA:66631

CEDNIK syndrome is a neurocutaneaous syndrome characterized by severe developmental abnormalities of the nervous system and aberrant differentiation of the epidermis. 